\title{
Positive current collector for Li\|Sb-Pb liquid metal battery
}

\author{
Takanari Ouchi and Donald R. Sadoway* \\ Department of Materials Science and Engineering \\ Massachusetts Institute of Technology
}

Cambridge, MA 02139-4307

\section{U.S.A.}

*Corresponding author: dsadoway@ mit.edu

\begin{abstract}
Corrosion in grid-scale energy storage devices adversely affects service lifetime and thus has a significant economic impact on their deployment. In this work, we investigate the corrosion of steel and stainless steels (SSs) as positive current collectors in the Li $\| \mathrm{Sb}-\mathrm{Pb}$ liquid metal battery. The erosion and formation of new phases on low-carbon steel, SS301, and SS430 were evaluated both in static conditions and under cell operating conditions. The cell performance is not adversely affected by the dissolution of iron or chromium but rather nickel. Furthermore, the in situ formation of a Fe-Cr-Sb layer helps mitigate the recession of SS430.
\end{abstract}

Key words: Liquid Metal Battery, Corrosion, $\mathrm{Sb}-\mathrm{Pb}$ alloy, liquid metal, stainless steel 


\section{Introduction}

Deployment of grid-scale batteries can result in a more reliable and resilient grid. They also enable the integration of intermittent renewable power sources into baseload generation on the conventional grid and facilitate a variety of functions ranging from peak shifting to frequency regulation. As a candidate for such a storage device, we have developed the liquid metal battery[1]. This consists of a low-density liquid metal negative electrode, an intermediate-density molten salt electrolyte, and a high-density liquid metal positive electrode, which self-segregate by density into three distinct layers due to their mutual immiscibility. In our previous work, a cell comprising liquid lithium $(\mathrm{Li})$ as the negative electrode, molten lithium halide salt as the electrolyte, and liquid antimony-lead $(\mathrm{Sb}-\mathrm{Pb})$ alloy as the positive electrode $(\mathrm{Li}|| \mathrm{Sb}-\mathrm{Pb})$ was demonstrated to be a practical embodiment of the concept [2].

During discharge of the $\mathrm{Li} \| \mathrm{Sb}-\mathrm{Pb}$ cell, a liquid $\mathrm{Li}$ negative electrode is oxidized to form $\mathrm{Li}^{+}$ which transits the electrolyte to the liquid $\mathrm{Sb}-\mathrm{Pb}$ positive electrode where the $\mathrm{Li}^{+}$ electrochemically reduces to neutral metallic $\mathrm{Li}$ which alloys with the $\mathrm{Sb}-\mathrm{Pb}$. This process is reversed on charging. The overall reaction and half-cell reactions are the following:

negative electrode reaction: $\mathrm{Li} \leftrightarrow \mathrm{Li}^{+}+\mathrm{e}^{-}$

positive electrode reaction: $\mathrm{Li}^{+}+\mathrm{e}^{-}+\mathrm{Sb}-\mathrm{Pb} \leftrightarrow \mathrm{Li}$ (in Sb-Pb)

overall reaction: $\mathrm{Li}+\mathrm{Sb}-\mathrm{Pb} \leftrightarrow \mathrm{Li}_{\text {(in } \mathrm{Sb}-\mathrm{Pb} \text { ) }}$

The Li $\| \mathrm{Sb}$-Pb cell performs with high round-trip coulombic and energy efficiencies (> $98 \%$, and $>70 \%$, respectively) and wide capability of current density $\left(>1 \mathrm{~A} \mathrm{~cm}^{-2}\right)$. 
In the assessment of the utility of such a battery, the most important performance metric is the levelized cost of the system, expressed in equation (4).

$$
C_{E}=\frac{M}{Q_{d} \cdot E_{d} \cdot N}+C_{e} \frac{E_{\text {in }}}{E_{\text {out }}}
$$

where $C_{E}$ is levelized cost $\left(\$ \cdot \mathrm{kWh}^{-1} \cdot \operatorname{cycle}^{-1}\right), M$ capital cost $(\$), Q_{\mathrm{d}}$ discharge capacity (Ah), $E_{\mathrm{d}}$ discharge voltage $(\mathrm{V}), N$ life span (cycles), $C_{e}$ cost of electricity $\left(\$ \cdot \mathrm{kWh}^{-1} \cdot\right.$ cycle $\left.^{-1}\right), E_{\text {in }}$ charge energy $(\mathrm{kWh})$, and $E_{\text {out }}$ discharge energy $(\mathrm{kWh})$. As shown in equation (4), the levelized cost varies inversely with service lifetime. In LMBs, there is no physical separator and no irreversible solid degradation mechanism; hence, there is little chance of performance loss through breakdown of active materials. Instead, the life span of LMBs depends mainly on the corrosion resistance of cell components. As part of a comprehensive effort to develop a low-cost, gridscale electrochemical energy storage device, we investigated corrosion phenomena in the Li $\mid \mathrm{Sb}$ $\mathrm{Pb}$ cell.

Within the electrochemical window of the LillSb-Pb cell $(0-1.2 \mathrm{~V}$ vs. Li), the lithium halide salts are not corrosive to ferrous metals, ceramics, or graphite [3]. Furthermore, a survey of the literature suggested that some ferrous alloys, including low carbon steels and stainless steels (SSs), have sufficient corrosion resistance against $\mathrm{Li}[4,5]$. The $\mathrm{Li} \| \mathrm{Sb}-\mathrm{Pb}$ cell fitted with a graphite positive current collector (PCC) exhibited no corrosion from the $\mathrm{Sb}-\mathrm{Pb}$ positive electrode and little loss of capacity $(0.002 \%$ per cycle). However, the graphite crucible lacks ductility, which potentially limits scalability and high-volume manufacturing. In this study, we investigated their performance of commonly available steels or stainless steels in the $\mathrm{Li} \| \mathrm{Sb}-\mathrm{Pb}$ cell owing to their low cost, machinability, and ductility. 
One of the typical methods to mitigate corrosion of stainless steels in liquid heavy metals, e.g., $\mathrm{Pb}-\mathrm{Bi}$, is controlling the oxygen concentration in the liquid alloy [6-8]. The dissolved oxygen with optimal concentration forms on the surface of the solid metal an oxide film, which becomes a protective layer against corrosion. However, due to presence of a liquid metal positive electrode the corrosion process of the PCC is quite complicated in a $\mathrm{Li} \| \mathrm{Sb}-\mathrm{Pb}$ cell. The $\mathrm{Li}$ metal negative electrode, which has an oxygen affinity that is higher than that of most other elements, dramatically reduces the partial pressure of oxygen in the system. Furthermore, the concentration of lithium in the liquid positive electrode varies with state of charge as the battery operates. Therefore, we were motivated to find a new concept for mitigating the corrosion by liquid metals to allow the use of steel and stainless steels as PCCs. In the present work as shown in Figure 1, we viewed this complicated process from two extreme conditions: (1) fully charged (tantamount to corrosion by lithium-free $\mathrm{Sb}-\mathrm{Pb}$ alloy), and (2) operating (consideration of the effects of lithium alloying and dealloying). We investigated the corrosion behavior of low carbon steel (1018), Fe-Ni-Cr based stainless steel (SS301), and Fe-Cr based stainless steel (SS430) and analyzed their performance in terms of their material chemistry. 
(a)

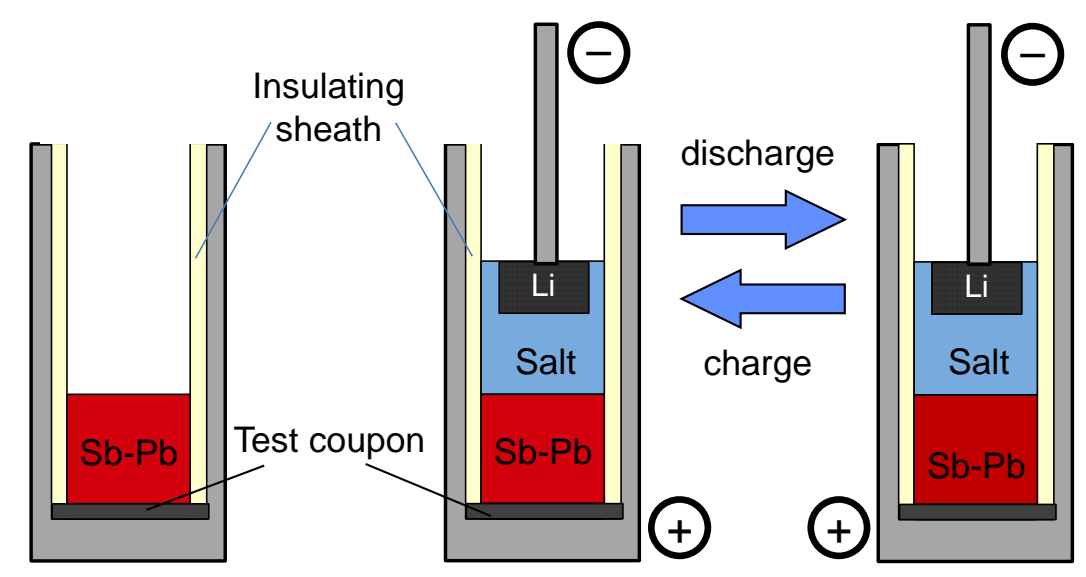

Figure 1 Cross-sectional views of test conditions: (a) Sb-Pb alloy, (b) fully-charged state, and (c) operating. The insulating sheath is boron nitride. The negative current collector consists of pure iron foam and SS18-7 rod. The positive current collector was low-carbon steel (1018).

\section{Materials and methods}

The test coupons in this work were iron film (1 mm thick, 99.995\%, Alfa Aesar), nickel film (1 mm thick, 99.9945\%, Alfa Aesar), chromium cube (6.35 mm, 99.95\%, Alfa Aesar), low-carbon steel film (1 mm thick, McMaster-Carr), SS301 film (1 mm thick, McMaster-Carr), and SS430 film (1 mm thick, McMaster-Carr). The compositions of low carbon steel, SS301, and SS430 are listed in Table 1. Test coupons were polished with diamond pastes, $1 \mu \mathrm{m}$ in diameter. These cells were charged with $0.32 \mathrm{~g}$ of Li (99.9\%, Sigma Aldrich), $2.1 \mathrm{~g}$ of Sb (99.999\%, Alfa Aesar), and $8.3 \mathrm{~g}$ of $\mathrm{Pb}(99.999 \%$, Alfa Aesar). The $\mathrm{Sb}-\mathrm{Pb}$ alloy was prepared with the composition of $30-70 \mathrm{~mol} \%$. To evaluate the corrosion behavior in a fully-charged cell, the test coupons were placed in liquid $\mathrm{Sb}-\mathrm{Pb}$ alloy as shown in Figure 1 (a). Then, the corrosion behavior of the test coupons in the cell at various charge-discharge conditions was evaluated by passing current through the cells shown in Figure 1 (b) and (c). A low-carbon steel (1018) crucible was used as the cell body. The dimensions of the low-carbon steel crucible were $25 \mathrm{~mm}$ in outer diameter, 83 
$\mathrm{mm}$ in height, $77 \mathrm{~mm}$ in depth, and $20 \mathrm{~mm}$ in inner diameter. The test coupons were placed on the bottom of the cell. A boron nitride sheath, $16.3 \mathrm{~mm}$ inner diameter and $20 \mathrm{~mm}$ outer diameter, was inserted to press the test coupons down to the bottom of the crucible. The negative current collector (NCC) consisted of an 18-8 stainless steel threaded rod and a column-shaped Fe-Ni foam. The Fe-Ni foam was $13 \mathrm{~mm}$ in diameter, $5 \mathrm{~mm}$ tall, pore diameter $\sim 380 \mu \mathrm{m}$. The foam NCC was positioned $15 \mathrm{~mm}$ above the bottom of the PCC. By surface tension the foam NCC holds lithium and keeps it away from the boron nitride. The surface area of the positive electrode was $2.09 \mathrm{~cm}^{2}$. The cells were charge-discharge cycled at $250 \mathrm{~mA} \mathrm{~cm}$ current density for 100 times using battery testers (BR2000, Arbin, and Model 4300, Maccor). All tests were done in a test vessel of the type shown in Figure 2 at a constant temperature of $450 \pm 0.5{ }^{\circ} \mathrm{C}$ under $\mathrm{Ar}$ atmosphere. The measured oxygen level from the outlet of the test vessel was less than $0.01 \mathrm{ppm}$. The salt was a mixture of lithium fluoride (ultra-dry 99.99\%, Alfa Aesar), lithium chloride (ultradry 99.995\%, Alfa Aesar), and lithium iodide (ultra-dry 99.999\%, Alfa Aesar) prepared following the processes described in previous works $[2,9,10]$. The composition of the LiF-LiClLiI molten salt electrolyte was $20-50-30 \mathrm{~mol} \%\left(\mathrm{~T}_{\mathrm{m}}=430^{\circ} \mathrm{C}\right)$. The sectional specimens were analyzed by scanning electron microscopy (SEM, JEOL6610), energy dispersive X-ray spectrometry (EDS, IXRF System, Model 55i), and electron probe microanalyzer (EPMA, JEOL-JXA-8200).

Table 1 Composition of test coupons (in wt\%).

\begin{tabular}{cccccccccc}
\hline & $\mathrm{Fe}$ & $\mathrm{Cr}$ & $\mathrm{Ni}$ & $\mathrm{C}$ & $\mathrm{Mn}$ & $\mathrm{Mo}$ & $\mathrm{Si}$ & $\mathrm{S}$ & $\mathrm{P}$ \\
\hline 1018 & 98.36 & 0.06 & 0.04 & 0.09 & 1.03 & 0.01 & 0.01 & 0.35 & 0.06 \\
SS301 & 73.54 & 17.41 & 7.29 & 0.09 & 0.91 & 0.22 & 0.5 & 0.01 & 0.026 \\
SS430 & 82.16 & 16.6 & 0.29 & 0.04 & 0.44 & 0.06 & 0.39 & - & 0.02 \\
\hline
\end{tabular}




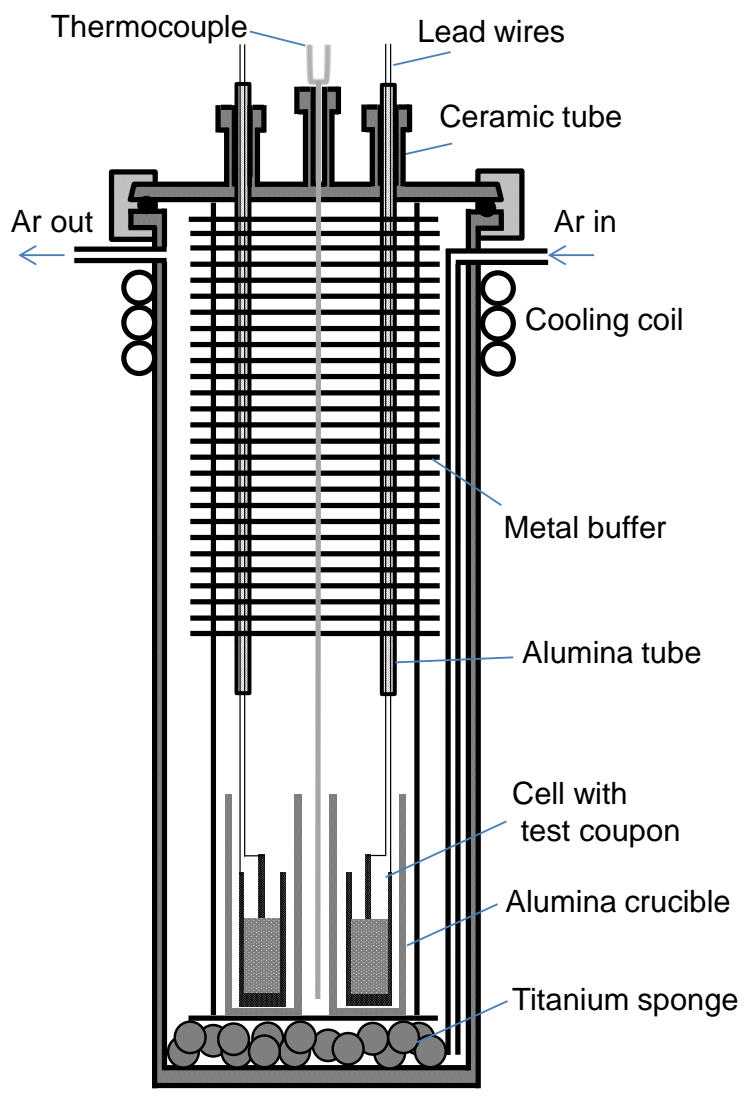

Figure 2 Schematic illustration of SS304 test vessel.

\section{Results and discussion}

\subsection{Static corrosion of $\mathrm{Fe}, \mathrm{Ni}, \mathrm{Cr}$ in $\mathrm{Sb}-\mathrm{Pb}$ alloy (fully charged cell)}

We began with an evaluation of the corrosion of the steels by pure liquid $\mathrm{Sb}-\mathrm{Pb}$ alloy representing a fully-charged state (Figure 1a) Lil|Sb-Pb cell. The corrosion of the PCC in liquid $\mathrm{Sb}-\mathrm{Pb}$ may involve the following processes: (1) dissolution of PCC into the liquid $\mathrm{Sb}-\mathrm{Pb},(2)$ thermal and concentration gradient assisted mass transfer in $\mathrm{PCC}$ and liquid $\mathrm{Sb}-\mathrm{Pb}$, (3) dissolution penetration of liquid metals into solid metals with formation of intermetallic solid solutions or new compounds. To the best of our knowledge, there has been no investigation of the corrosion of stainless steels in liquid $\mathrm{Sb}-\mathrm{Pb}$ alloy; accordingly, thermodynamic evaluation of metals composing steels and stainless steels, such as iron (Fe), nickel (Ni), and chromium $(\mathrm{Cr})$, 
equilibrated with liquid $\mathrm{Sb}-\mathrm{Pb}$ alloy was the first step. To evaluate the formation of intermetallic compounds, static corrosion testing of pure $\mathrm{Fe}, \mathrm{Ni}$, and $\mathrm{Cr}$ was carried out. The cross-sections at the interfaces between coupons and liquid metal $\mathrm{Sb}-\mathrm{Pb}$ alloys after $500 \mathrm{~h}$ immersion are shown in Figure 3. The layers of $\mathrm{Fe}-\mathrm{Sb}, \mathrm{Ni}-\mathrm{Sb}$, and $\mathrm{Cr}-\mathrm{Sb}$ intermetallic alloys were observed in the cross sectional SEM shown in Figure 3 (a-c). The line scans of composition are shown in Figure 3(d-f). A small quantity of oxygen $(\mathrm{O})$ and $\mathrm{Pb}$ were found in the intermetallic layers. These results suggest the $\mathrm{Sb}$ dominantly alloyed with $\mathrm{Ni}, \mathrm{Fe}$, and $\mathrm{Cr}$ in $\mathrm{Sb}-\mathrm{Pb}$ alloys. According to the phase diagram [11-16] and composition analysis of the sample shown in Figure 3, the intermetallic layers are considered to be $\mathrm{FeSb}_{2}, \mathrm{Ni}_{3} \mathrm{Sb}, \mathrm{Ni}_{5} \mathrm{Sb}_{2}, \mathrm{NiSb}_{2}, \mathrm{CrSb}$, and $\mathrm{CrSb}_{2}$. Layer thickness was observed to follow $\mathrm{Ni}>\mathrm{Fe}>\mathrm{Cr}$. As the formation of intermetallic solid solutions and compounds is affected by dissolution of solid metal and penetration of liquid metal into solid metal, our data suggest that the solubilities of $\mathrm{Fe}, \mathrm{Ni}$, and $\mathrm{Cr}$ in $\mathrm{Sb}-\mathrm{Pb}$ rank $\mathrm{Ni}>\mathrm{Fe}>\mathrm{Cr}$, in contrast to those in a $\mathrm{Pb}$ and a $\mathrm{Pb}-\mathrm{Bi}$ eutectic (LBE) alloy, $\mathrm{Ni}>\mathrm{Cr}>\mathrm{Fe}[6,7]$. This difference in behavior indicates that the increase in the concentration of $\mathrm{Sb}$ in $\mathrm{Sb}-\mathrm{Pb}$ alloy is accompanied by an increase in the solubility of Fe. These data further suggest that the nickel content of the PCC needs to be reduced. 


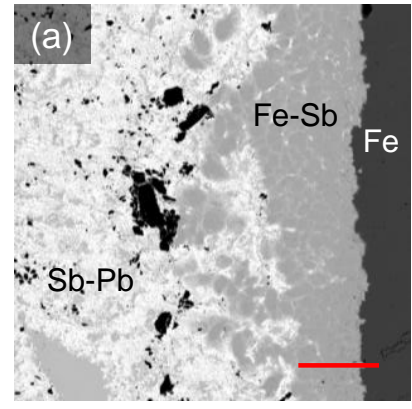

(d)

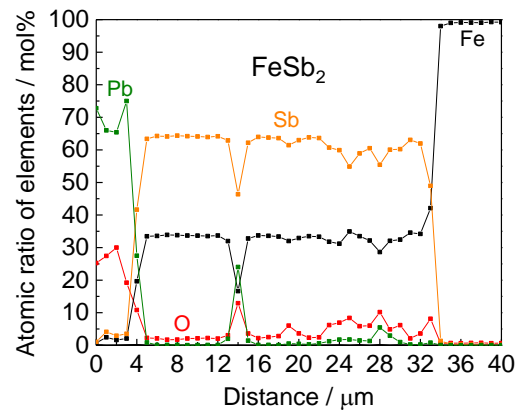

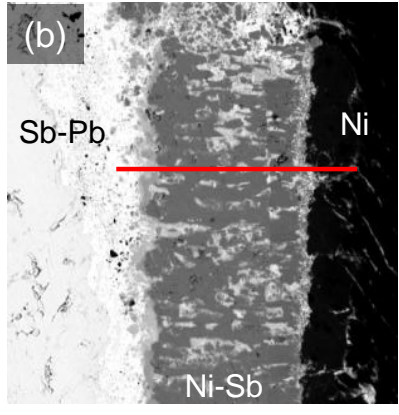

(e)

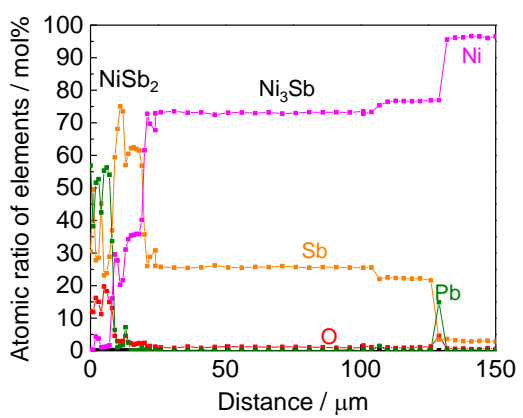

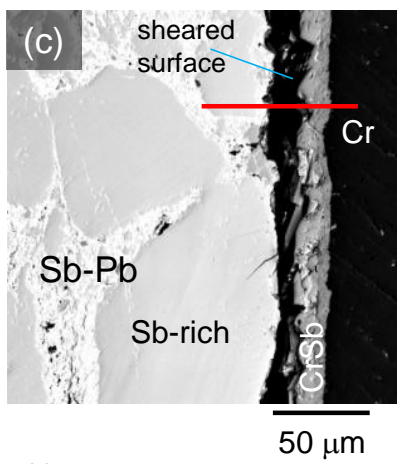

(f)

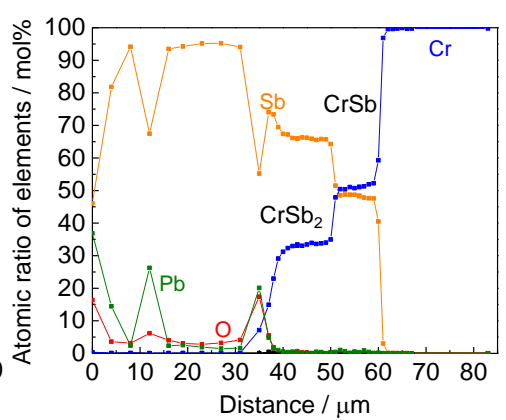

Figure 3 Cross-sectional SEM images and their composition analyses (EPMA): (a) Fe, (b) Ni, (C) $\mathrm{Cr}$, (d) composition analysis of $\mathrm{Fe}$, (e) composition analysis of $\mathrm{Ni}$, and (f) composition analysis of $\mathrm{Cr}$. The operating temperature and time were $450{ }^{\circ} \mathrm{C}$ and 500 hour, respectively. The composition analyses were done on the red lines in (a-c).

\subsection{Static corrosion of low-carbon steel, SS301, and SS430}

In order to elucidate the effects of the concentration of $\mathrm{Fe}, \mathrm{Ni}$, and $\mathrm{Cr}$ in steel and stainless steels, a low-carbon steel (1018), a FeNiCr-based stainless steel (SS301), and a FeCr-based stainless steel (SS430) were selected for the investigation. Static corrosion tests of 1018, SS301, and SS430 in the liquid $\mathrm{Sb}-\mathrm{Pb}$ alloy were performed. Cross sections of coupons after $500 \mathrm{~h}$ immersion are shown in Figure 4. On 1018, SS301 and SS430, layers of Fe-Sb alloy $(\sim 100 \mu \mathrm{m}$ in thick), Fe-Ni-Cr-Sb alloy $(\sim 10 \mu \mathrm{m}$ thick $)$, and $\mathrm{Fe}-\mathrm{Cr}-\mathrm{Sb}(\sim 10 \mu \mathrm{m}$ thick $)$ were formed, respectively. The composition of the $\mathrm{Fe}-\mathrm{Sb}$ alloy on the steel 1018 was $\mathrm{FeSb}_{2}$. Small quantities 
of $\mathrm{Cr}$ and $\mathrm{Ni}$ were found in the alloys on SS301 and SS430; in contrast, almost no detectable $\mathrm{Cr}$ and Ni were confirmed in the Sb-Pb alloy. No clear recession was observed on SS301 and SS430.

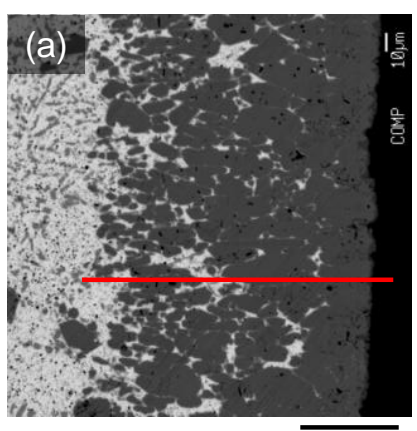

$50 \mu \mathrm{m}$ (d)

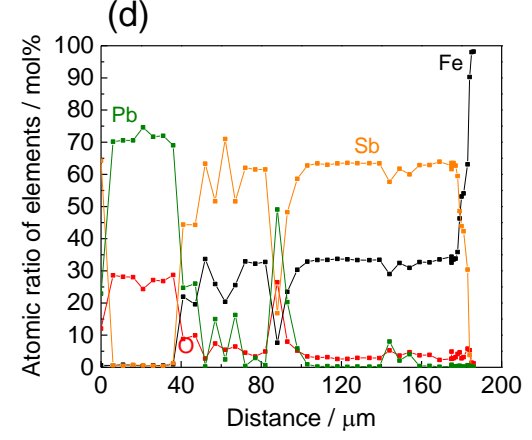

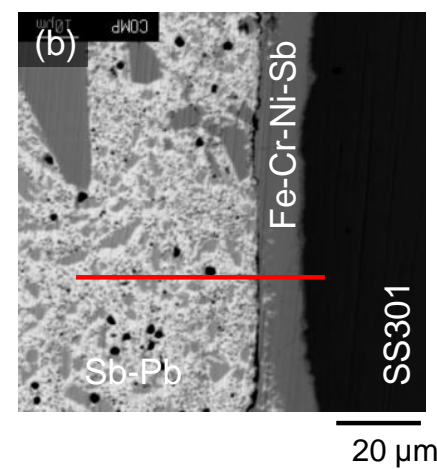

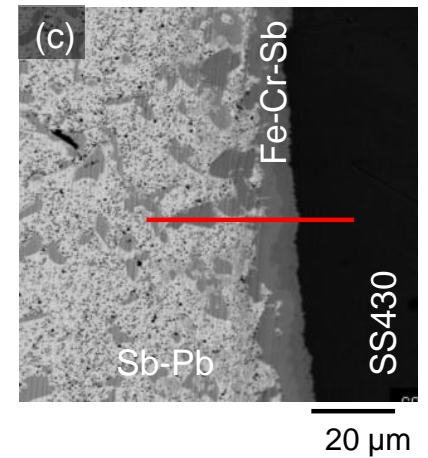

(e)

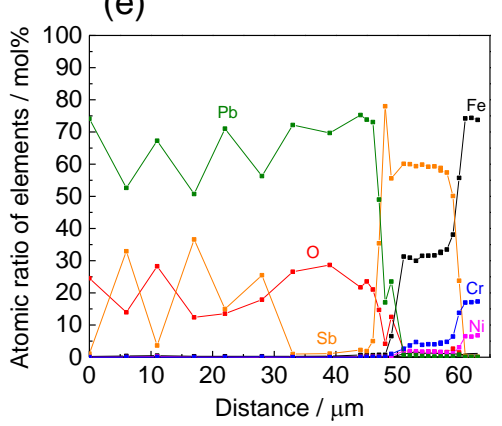

(f)

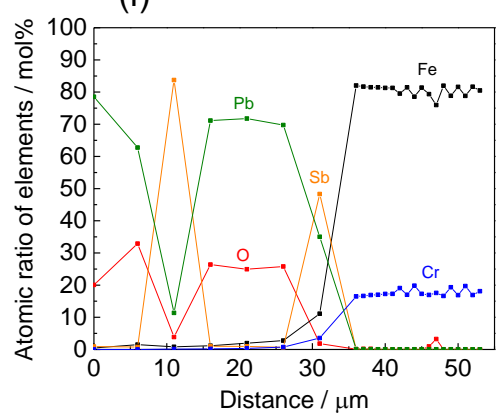

Figure 4 Cross-sectional SEM images and their composition analyses (EPMA): (a) low-carbon steel, (b) SS301, (C) SS430, (d) composition analysis of low-carbon steel, (e) composition analysis of SS301, and (f) composition analysis of SS430. The operating temperature and time were $450{ }^{\circ} \mathrm{C}$ and 500 hour, respectively. The composition analyses were done on the red lines in (a-c).

\subsection{Cell performance}

The corrosion of the steels and stainless steels in operating $\mathrm{Li} \| \mathrm{Sb}-\mathrm{Pb}$ cells was evaluated by placing the test coupons as PCCs in cells that were charged/discharged for $500 \mathrm{~h}$. The important factors in the selection of a PCC are: (1) voltage change, (2) capacity fade, and (3) recession of PCC with cycling. 
Figure 5 (a) shows charge-discharge voltage-time traces of the cells during the 20th cycle. There was no difference in cell charge-discharge performance by changing the PCC materials in Figure 5 (a). The nominal discharge voltage did not change with cycling with all types current collectors as shown in Figure 5 (b). This indicates the dissolved $\mathrm{Fe}, \mathrm{Ni}, \mathrm{Cr}$ have a minor effect on the voltage of the cell. However, the discharge capacity fade rate with cycling varies with the composition of the PCC. The capacity fade rate of 1018, SS301, and SS430 were $0.05 \%$ per cycle, $0.35 \%$ per cycle, and $0.06 \%$ per cycle, respectively (Figure $5 \mathrm{c}$ ). According to data available in the literature the first lithiation potentials of $\mathrm{FeSb}_{2}[17-19], \mathrm{CrSb}_{2}[19], \mathrm{NiSb}_{2}[20]$ at room temperature are lower than that of $\mathrm{Sb}-\mathrm{Pb}(\sim 0.88 \mathrm{~V})$ [2]. Furthermore, the first lithiation potentials of $\mathrm{FeSb}_{2}(\sim 0.62 \mathrm{~V})$ and $\mathrm{CrSb}_{2}(\sim 0.57 \mathrm{~V})$ are higher than the discharge cutoff voltage in this work $(0.5 \mathrm{~V})$. On the other hand the lithiation potential of $\mathrm{NiSb}_{2}$ is small $(\sim 0.48 \mathrm{~V})$, almost the same as the discharge cutoff voltage. This suggests that as the cell cycles it gradually loses active $\mathrm{Sb}$ by forming $\mathrm{Ni}-\mathrm{Sb}$ intermetallics.

(a)

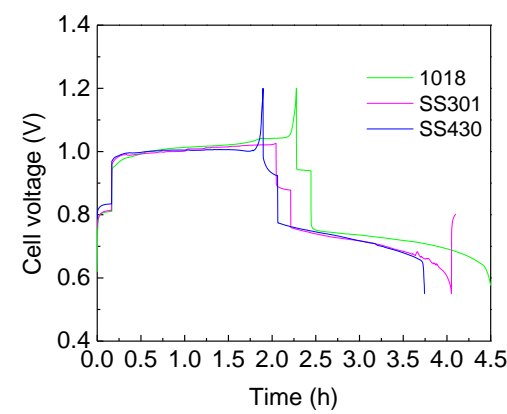

(b)

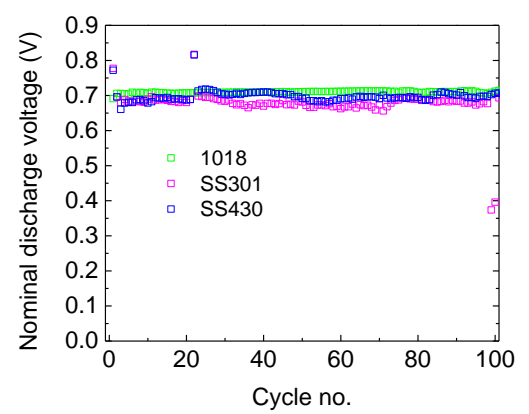

(c)

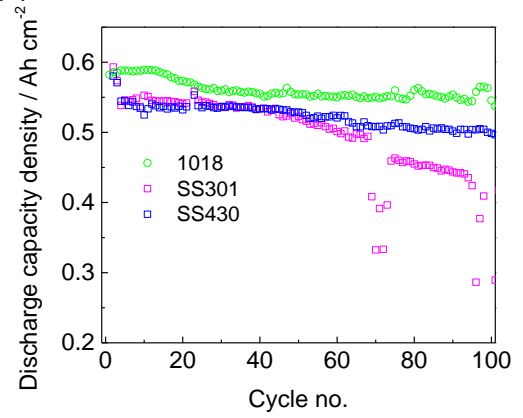

Figure 5 Cell cycling performance of Li |S Sb-Pb cells: (a) charge-discharge voltage-time trace of 20 th cycle, (b) variation in average discharge voltage with cycling, (c) variation in discharge capacity density with cycling. Current density was $250 \mathrm{~mA} \mathrm{~cm}$. 
cycles

the

cells

were

cooled and sectioned.

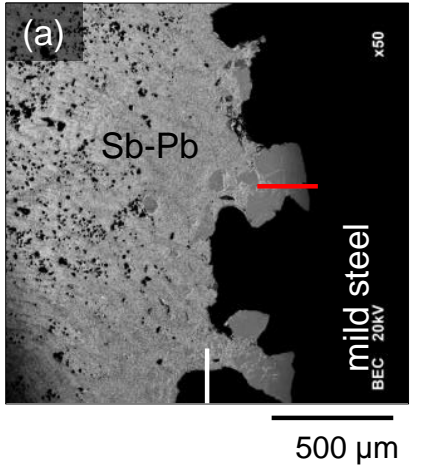

(d)

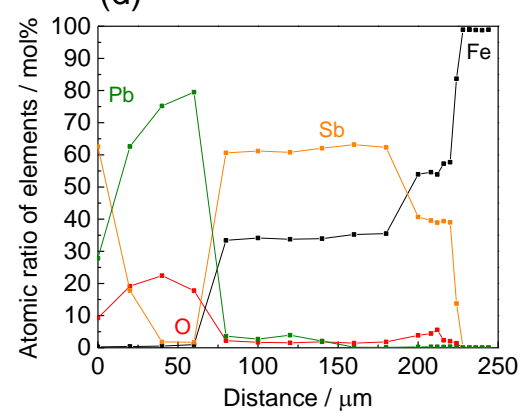

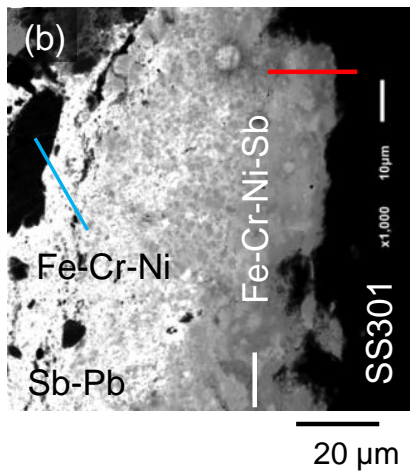

(e)

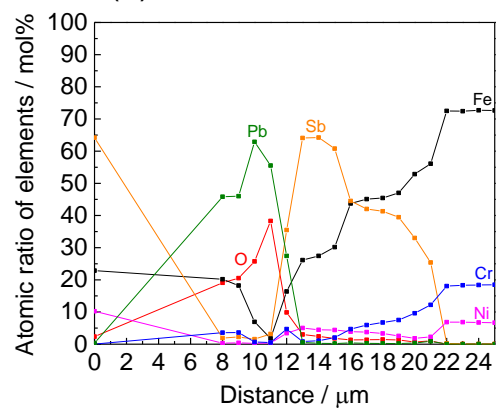

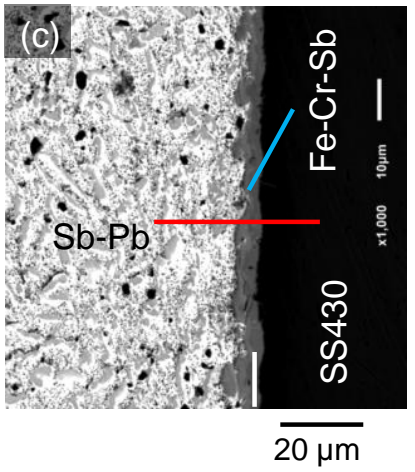

(f)

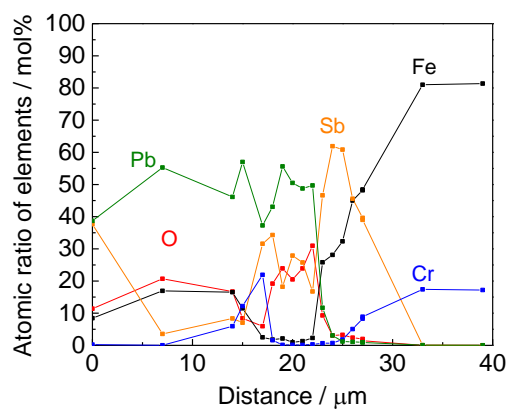

shows SEM images. Obvious recession with no Fe-Sb layer was confirmed on 1018. Although the Fe-Cr-Ni-Sb layer formed on SS301, some recession occurred. In contrast, a thin uniform Fe$\mathrm{Cr}-\mathrm{Sb}$ layer was observed on SS430 which exhibited no recession. During discharge, Li alloys preferentially with $\mathrm{Sb}$ in the positive electrode to form $\mathrm{Li}-\mathrm{Sb}-\mathrm{Pb}$ alloys of low $\mathrm{Pb}$ concentration; then on charging the $\mathrm{Li}$ dealloys from the $\mathrm{Li}-\mathrm{Sb}-\mathrm{Pb}$ alloys[2]. This variation in lithium concentration has the potential to destroy the surface layer of Fe-Sb and Fe-Cr-Ni-Sb. However, it was determined in this study that $\mathrm{Fe}-\mathrm{Cr}-\mathrm{Sb}$ alloy is a stable intermetallic compound over the entire range of lithiation.

Furthermore, the growth rate of the Fe-Cr-Sb layer is slow as shown in Figure 7. Even with the linear approximation, the growth rate was $63 \mu \mathrm{m}$ per year. These results suggest that among the 
materials evaluated in this work SS430 is the candidate PCC for Li||Sb-Pb LMB although the $475^{\circ} \mathrm{C}$ embrittlement phenomenon is a concern.

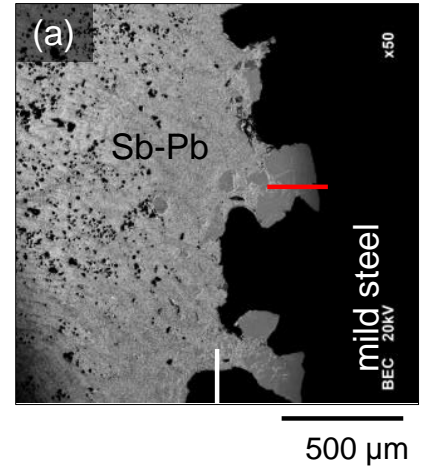

(d)

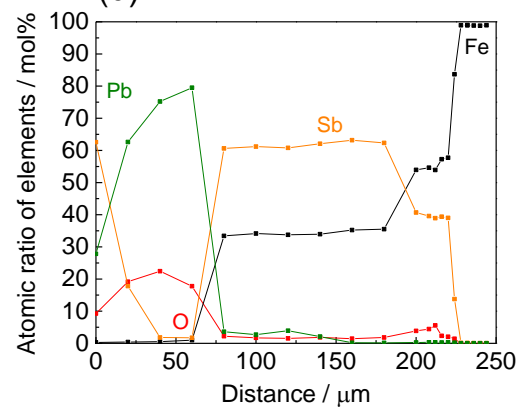

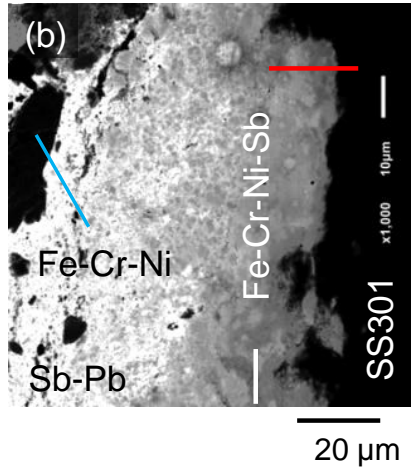

(e)

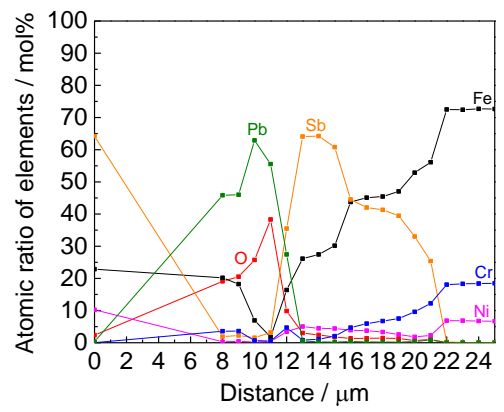

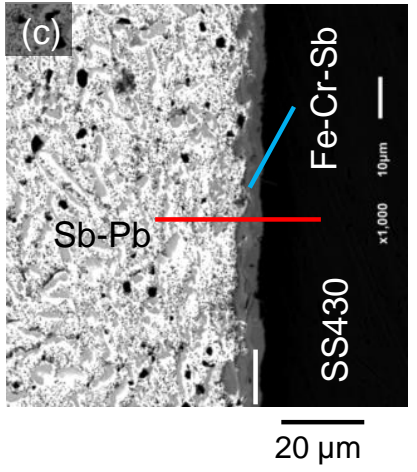

(f)

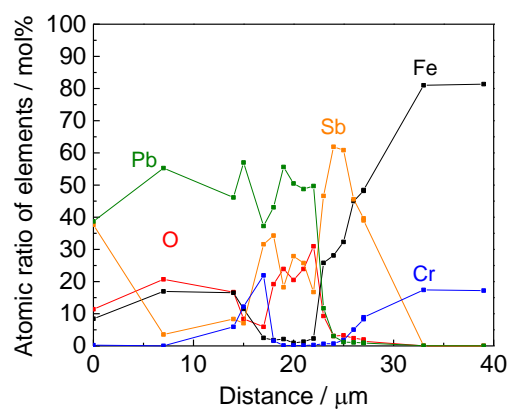

Figure 6 Cross-sectional SEM images and their composition analyses (EPMA): (a) low-carbon steel, (b) SS301, (C) SS430, (d) composition analysis of low-carbon steel, (e) composition analysis of SS301, and (f) composition analysis of SS430. The operating temperature and time were $450{ }^{\circ} \mathrm{C}$ and 500 hour, respectively. The composition analyses were done on the red lines in (a-c). The original surfaces of the test coupons were depicted with white lines in the images.

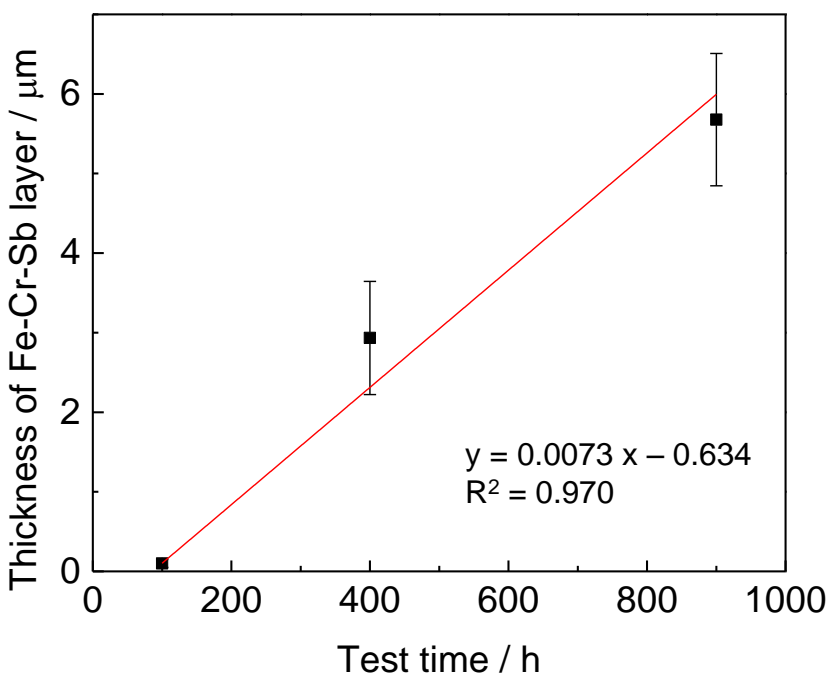


Figure 7 Growth of $\mathrm{Fe}-\mathrm{Cr}-\mathrm{Sb}$ intermetallic layer with cycling time.

\section{Conclusion}

In this work, we demonstrated a concept for prolonging the service lifetime of positive current collectors in LMBs. The formation of new layers of protective $\mathrm{Fe}-\mathrm{Cr}-\mathrm{Sb}$ alloys extends the use of low-cost structural metals as cell components in LMBs without any additional processes (e.g., surface treatment). Although there was no obvious effect of embrittlement of SS430 at $\sim 475^{\circ} \mathrm{C}$ due to precipitation of $\mathrm{Cr}$-enriched $\alpha^{\prime}$ phase, this will motivate us for further investigation to find a composition of stainless steel that balances ductility and corrosion resistance.

\section{Acknowledgment}

Financial support from Total, S.A. is gratefully acknowledged. 


\section{References}

[1] H. Kim, D.A. Boysen, J.M. Newhouse, B.L. Spatocco, B. Chung, P.J. Burke, D.J. Bradwell, K. Jiang, A.A. Tomaszowska, K. Wang, W. Wei, L.A. Ortiz, S.A. Barriga, S.M. Poizeau, D.R. Sadoway, Chemical Reviews, 113 (2013) 2075-2099.

[2] K. Wang, K. Jiang, B. Chung, T. Ouchi, P.J. Burke, D.A. Boysen, D.J. Bradwell, H. Kim, U. Muecke, D.R. Sadoway, Nature, 514 (2014) 348-350.

[3] P.F. Tortorelli, J.H. DeVan, J.R. Keiser, Journal of Nuclear Materials, 103 (1981) 675-680.

[4] G.C. Burrow, M.G. Down, C. Bagnall, Journal of Nuclear Materials, 103 (1981) 657-662.

[5] Q. Jiapu, C. Jiming, C. Jinbiao, X. Zengyu, W. Weihao, P. Chuanjie, Journal of Nuclear Materials, 179 (1991) 603-606.

[6] J. Zhang, N. Li, Journal of Nuclear Materials, 373 (2008) 351-377.

[7] N. Li, Journal of Nuclear Materials, 300 (2002) 73-81.

[8] M. Machut, K. Sridharan, N. Li, S. Ukai, T. Allen, Journal of Nuclear Materials, 371 (2007) 134-144.

[9] T. Ouchi, H. Kim, B.L. Spatocco, D.R. Sadoway, Nature Communications, 7 (2016) 10999.

[10] T. Ouchi, H. Kim, X. Ning, D.R. Sadoway, Journal of The Electrochemical Society, 161 (2014) A1898A1904.

[11] H. Okamoto, Fe-Sb (Iron-Antimony) Phase Diagram, ASM Alloy Phase Diagrams Database, P. Villars, editor-in-chief; H. Okamoto and K. Cenzual, section editors; http://www.asminternational.org, ASM International, Materials Park, OH, 2016.

[12] G.H. Cha, S.Y. Lee, P. Nash, Ni-Sb (Nickel-Antimony) Phase Diagram, ASM Alloy Phase Diagrams Database, P. Villars, editor-in-chief; H. Okamoto and K. Cenzual, section editors; http://www.asminternational.org, ASM International, Materials Park, OH, 2016.

[13] M. Venkatraman, J.P. Neumann, Cr-Sb (Chromium-Antimony) Phase Diagram, ASM Alloy Phase Diagrams Database, P. Villars, editor-in-chief; H. Okamoto and K. Cenzual, section editors; http://www.asminternational.org, ASM International, Materials Park, OH, 2016.

[14] E. Isaac, G. Tammann, Fe-Pb (Iron-lead) Phase Diagram, ASM Alloy Phase Diagrams Database, P. Villars, editor-in-chief; H. Okamoto and K. Cenzual, section editors; http://www.asminternational.org, ASM International, Materials Park, OH, 2016.

[15] P. Nash, Ni-Pb (Nickel-Lead) Phase Diagram, ASM Alloy Phase Diagrams Database, P. Villars, editorin-chief; H. Okamoto and K. Cenzual, section editors; http://www.asminternational.org, ASM International, Materials Park, $\mathrm{OH}, 2016$.

[16] M. Venkatraman, J.P. Neumann, $\mathrm{Cr}-\mathrm{Pb}$ (Chromium-Lead) Phase Diagram, ASM Alloy Phase Diagrams Database, P. Villars, editor-in-chief; H. Okamoto and K. Cenzual, section editors; http://www.asminternational.org, ASM International, Materials Park, OH, 2016.

[17] C. Villevieille, C.M. Ionica-Bousquet, B. Fraisse, D. Zitoun, M. Womes, J.C. Jumas, L. Monconduit, Solid State Ionics 192, (2011) 351-355.

[18] C. Villevieille, B. Fraisse, M.Womes, J.-C. Jumas, L. Monconduit, Journal of Power Sources 189 (2009) 324-330.

[19] Cheol-Min Park, Hun-Joon Sohn, Electrochimica Acta 55 (2010) 4987-4994.

[20] C. Villevieille, C.-M. Ionica-Bousquet, B. Ducourant, J.-C. Jumas, L. Monconduit, Journal of Power Sources 172 (2007) 388-394. 
Table 2 Composition of test coupons (in wt $\%$ ).

\begin{tabular}{cccccccccc}
\hline & $\mathrm{Fe}$ & $\mathrm{Cr}$ & $\mathrm{Ni}$ & $\mathrm{C}$ & $\mathrm{Mn}$ & $\mathrm{Mo}$ & $\mathrm{Si}$ & $\mathrm{S}$ & $\mathrm{P}$ \\
\hline 1018 & 98.36 & 0.06 & 0.04 & 0.09 & 1.03 & 0.01 & 0.01 & 0.35 & 0.06 \\
SS301 & 73.54 & 17.41 & 7.29 & 0.09 & 0.91 & 0.22 & 0.5 & 0.01 & 0.026 \\
SS430 & 82.16 & 16.6 & 0.29 & 0.04 & 0.44 & 0.06 & 0.39 & - & 0.02 \\
\hline
\end{tabular}

Table 3 Standard free energy change of reactions and equilibrium reaction potential between lithium and intermetallic compounds at $450{ }^{\circ} \mathrm{C}$.

\begin{tabular}{ccc}
\hline Reactions & $\Delta \mathrm{G}^{\mathrm{o}} / \mathrm{kJmol}^{-1}$ & $\mathrm{E}^{\mathrm{o}} / \mathrm{V}$ vs. Li \\
\hline $4 \mathrm{Li}(l)+\mathrm{FeSb}_{2}(s)=2 \mathrm{Li}_{2} \mathrm{Sb}(s)+\mathrm{Fe}(s)$ & -426 & 1.10 \\
$6 \mathrm{Li}(l)+\mathrm{FeSb}_{2}(s)=2 \mathrm{Li}_{3} \mathrm{Sb}(s)+\mathrm{Fe}(s)$ & -592 & 1.02 \\
$2 \mathrm{Li}(l)+\mathrm{NiSb}(s)=\mathrm{Li}_{2} \mathrm{Sb}(s)+\mathrm{Ni}(s)$ & -90 & 0.466 \\
$3 \mathrm{Li}(l)+\mathrm{NiSb}(s)=\mathrm{Li}_{3} \mathrm{Sb}(s)+\mathrm{Ni}(s)$ & -173 & 0.597 \\
$2 \mathrm{Li}(l)+\mathrm{CrSb}(s)=\mathrm{Li}_{2} \mathrm{Sb}(s)+\mathrm{Cr}(s)$ & -161 & 0.835 \\
$3 \mathrm{Li}(l)+\mathrm{CrSb}(s)=\mathrm{Li}_{3} \mathrm{Sb}(s)+\mathrm{Cr}(s)$ & -244 & 0.843 \\
$4 \mathrm{Li}(l)+\mathrm{CrSb}_{2}(s)=2 \mathrm{Li}_{2} \mathrm{Sb}(s)+\mathrm{Cr}(s)$ & -412 & 1.07 \\
$6 \mathrm{Li}(l)+\mathrm{CrSb}_{2}(s)=2 \mathrm{Li}_{3} \mathrm{Sb}(s)+\mathrm{Cr}(s)$ & -578 & 1.00 \\
\hline
\end{tabular}




\section{Corrosion of positive current collector in $\mathrm{Li} \mid \mathrm{Sb}-\mathrm{Pb}$ liquid metal battery for grid-scale energy storage Takanari Ouchi, Donald R. Sadoway}


Fig. 1

(a)

(b)

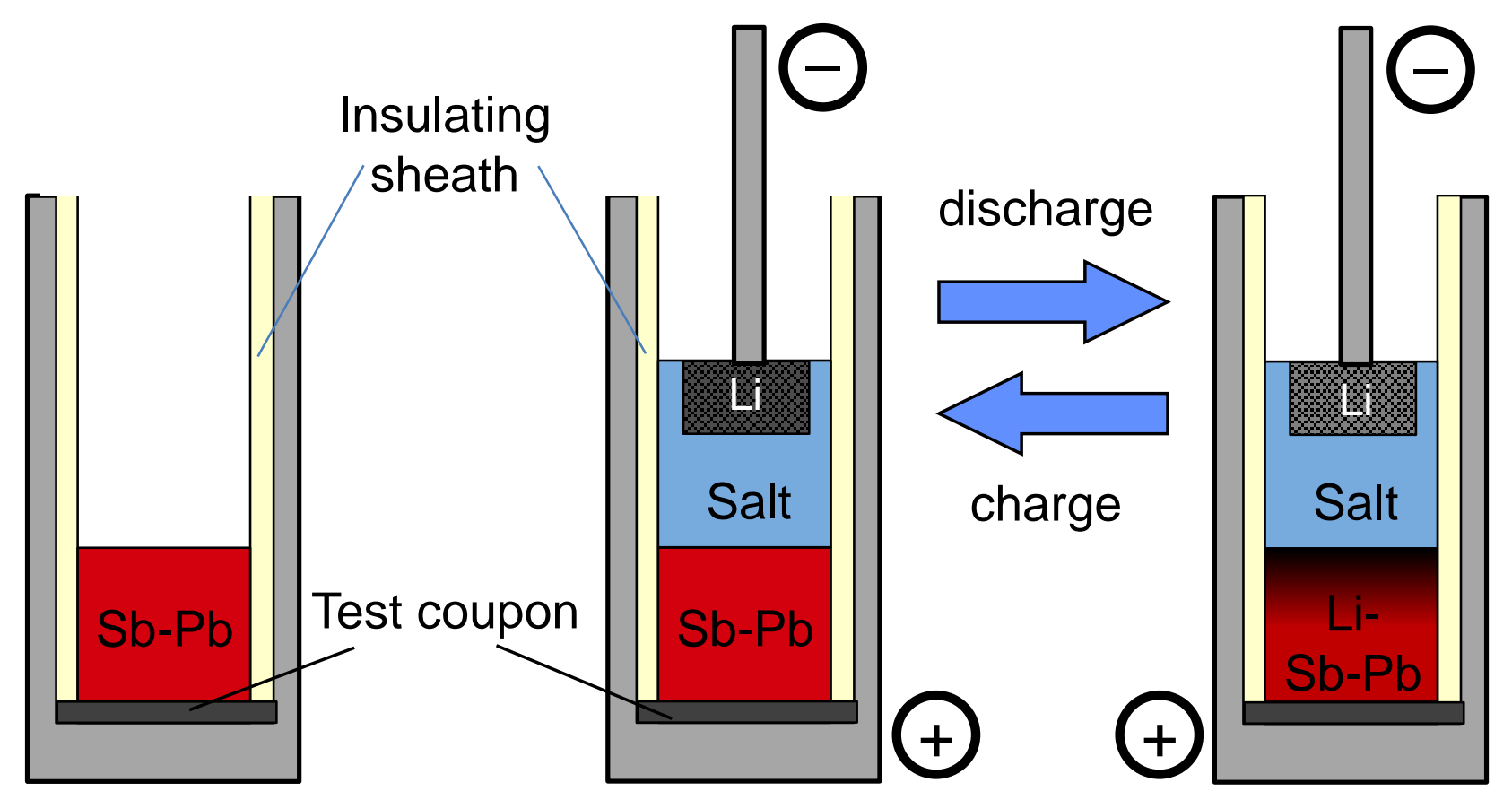

(c) 


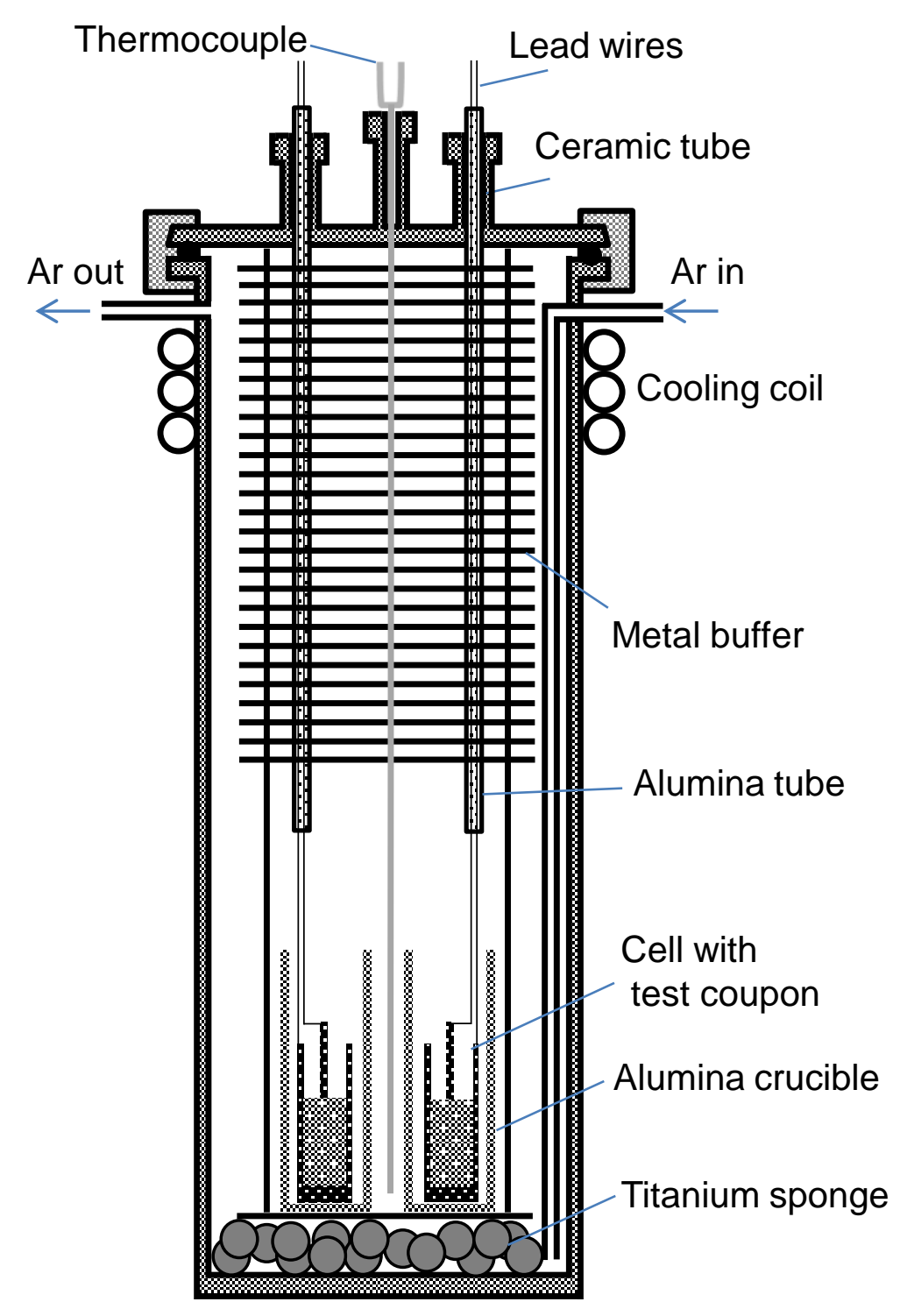


Fig. 3

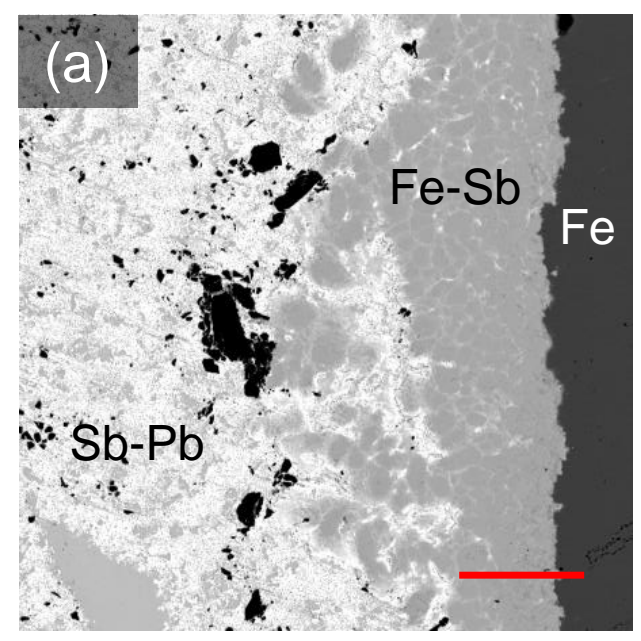

(d)

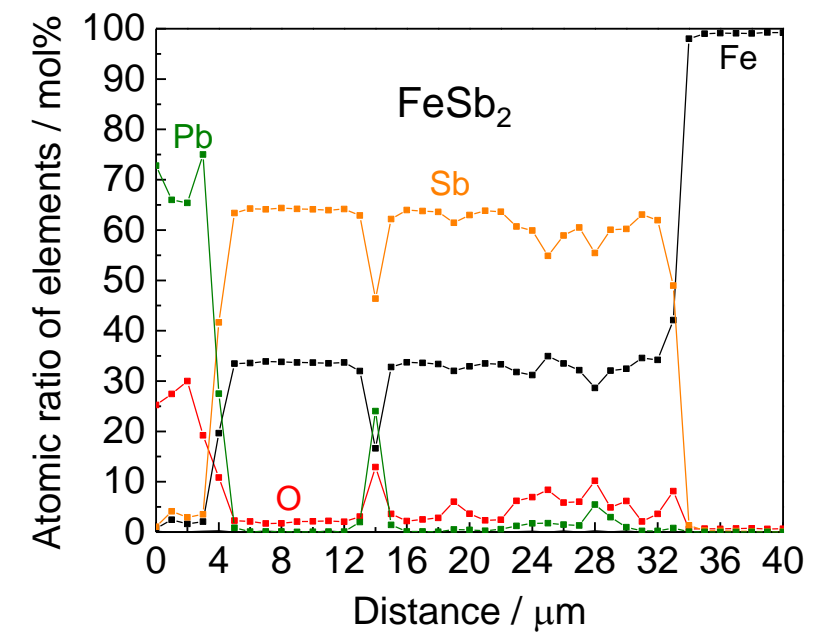

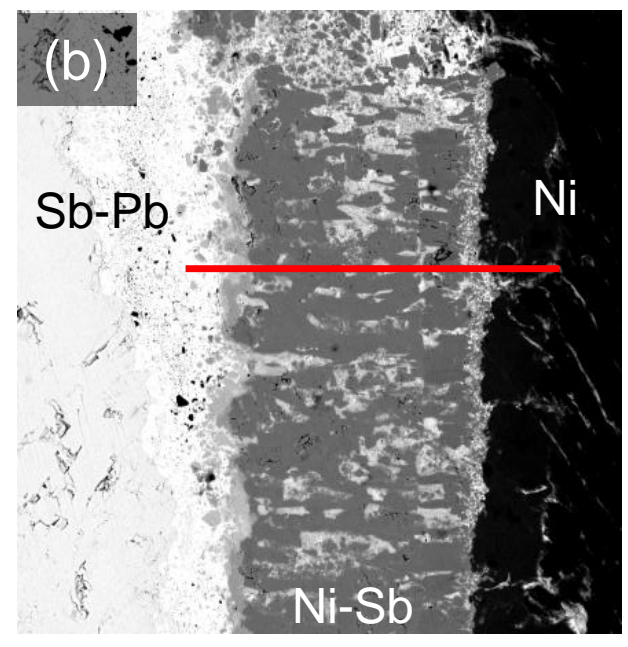

(e)

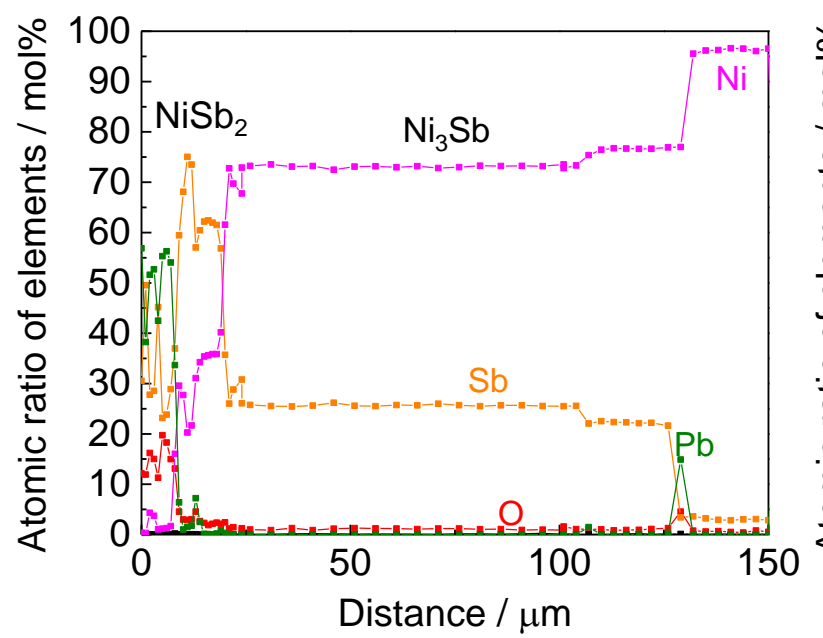

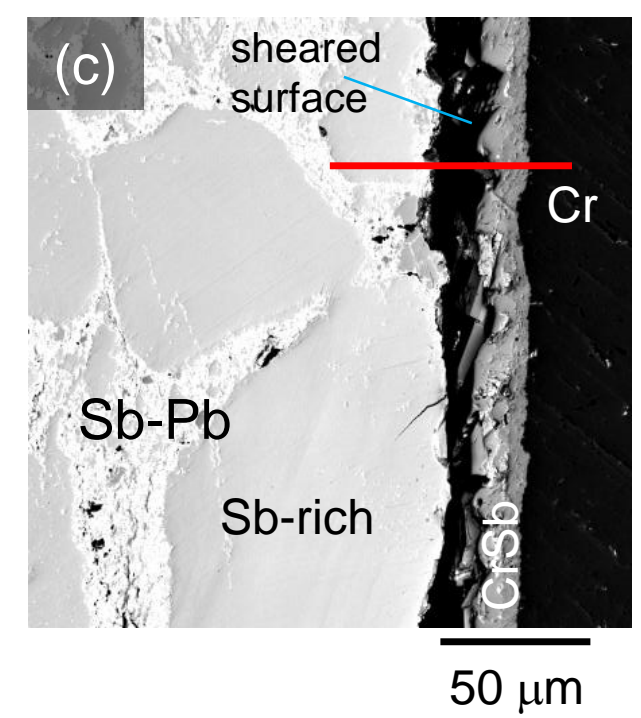

(f)

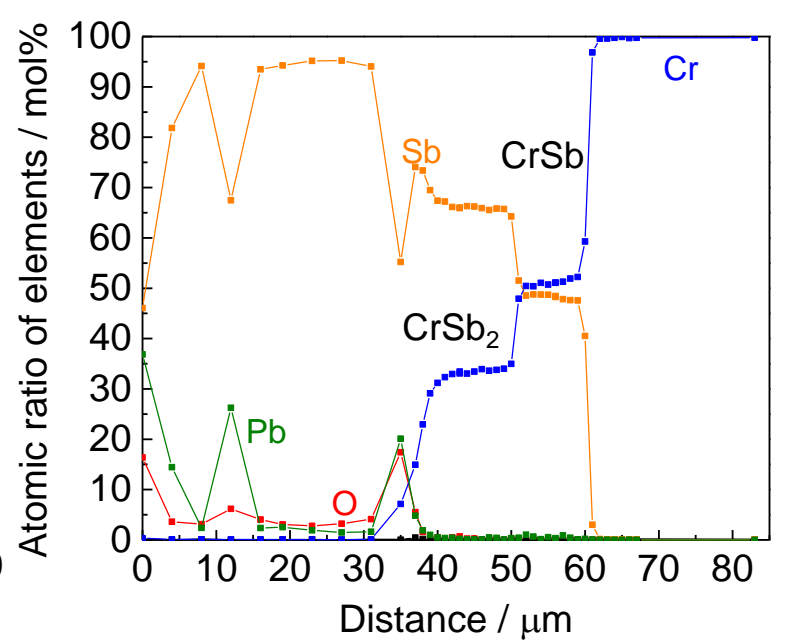


Fig. 4

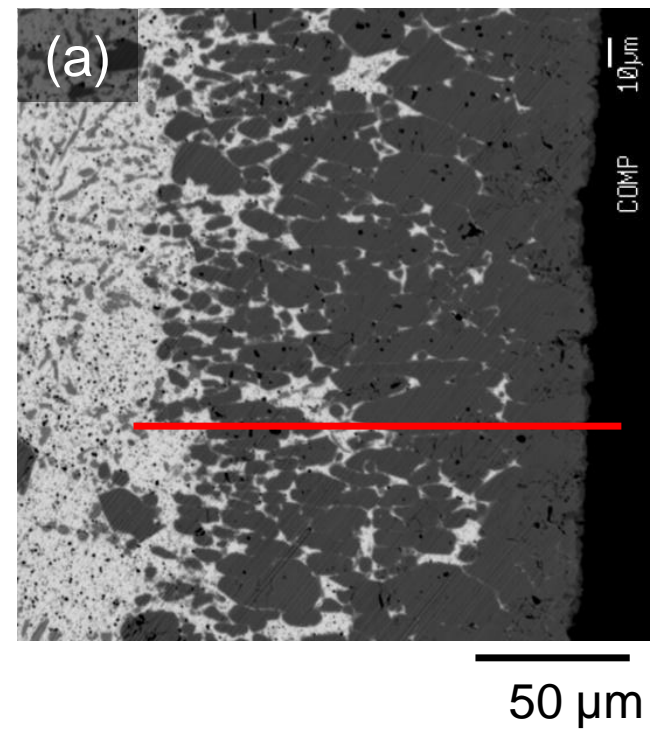

(d)

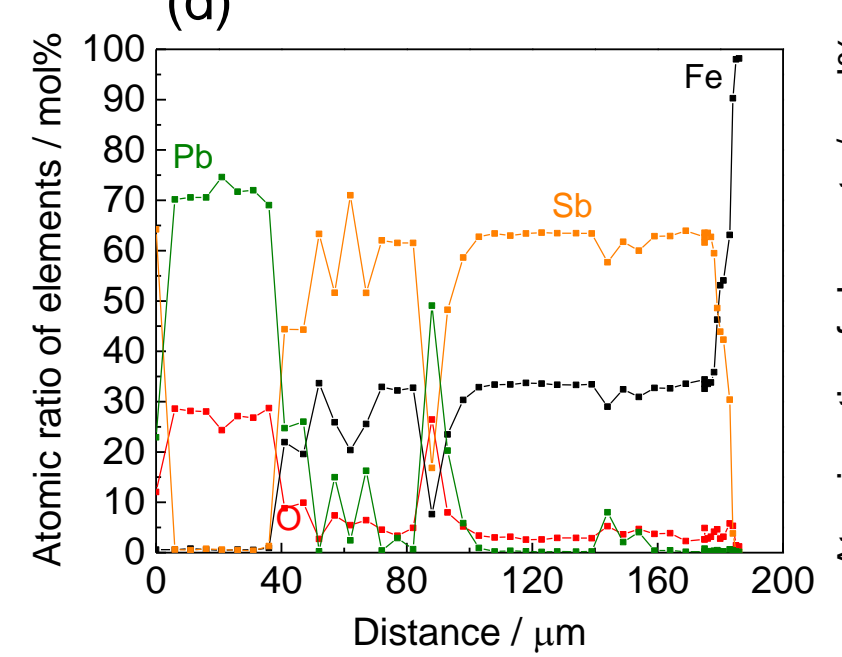

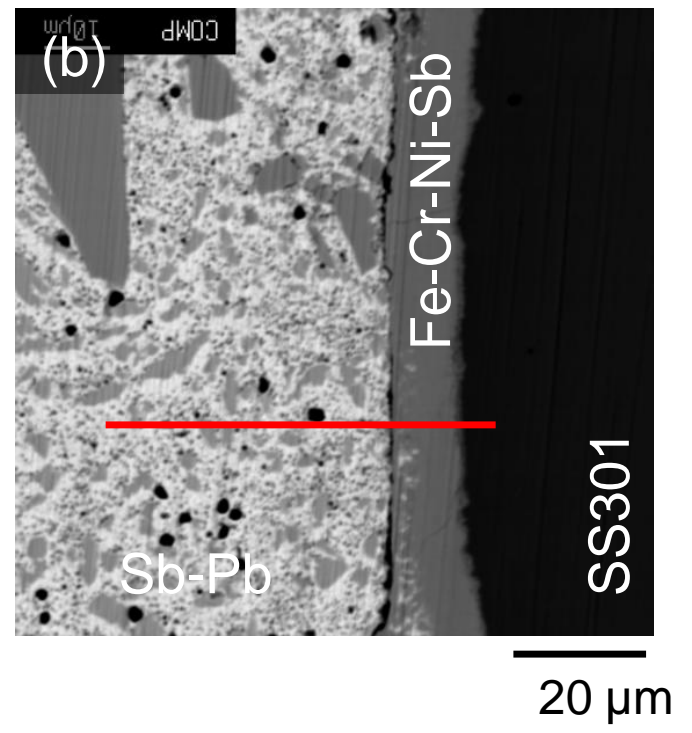

(e)

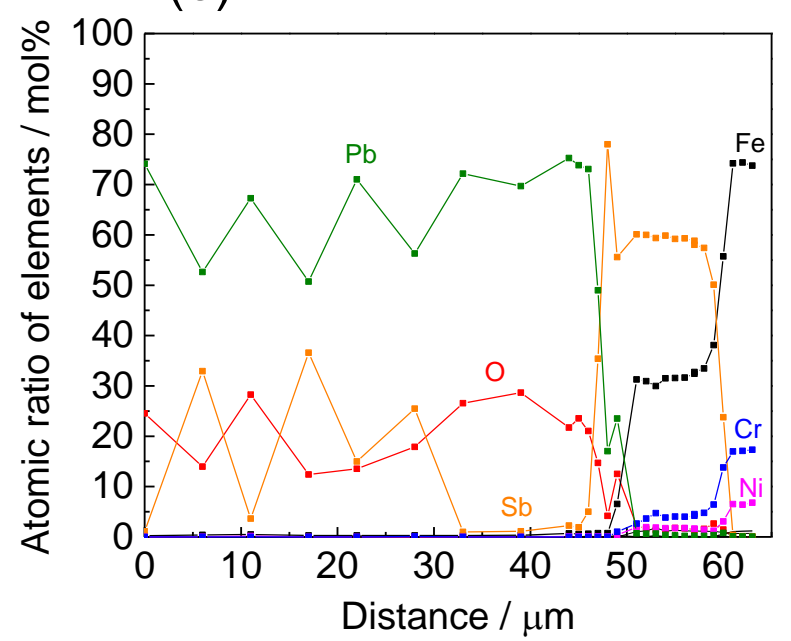

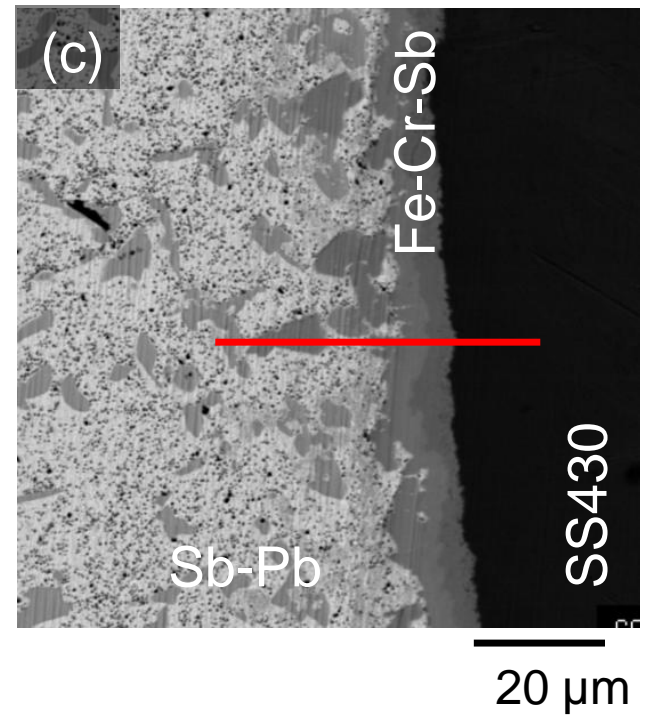

(f)

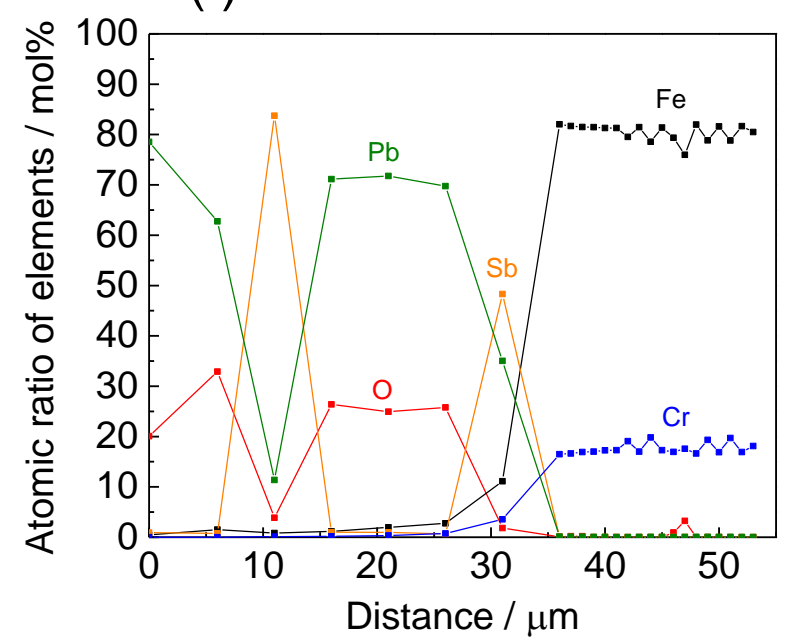




\section{Fig. 5}

(b)

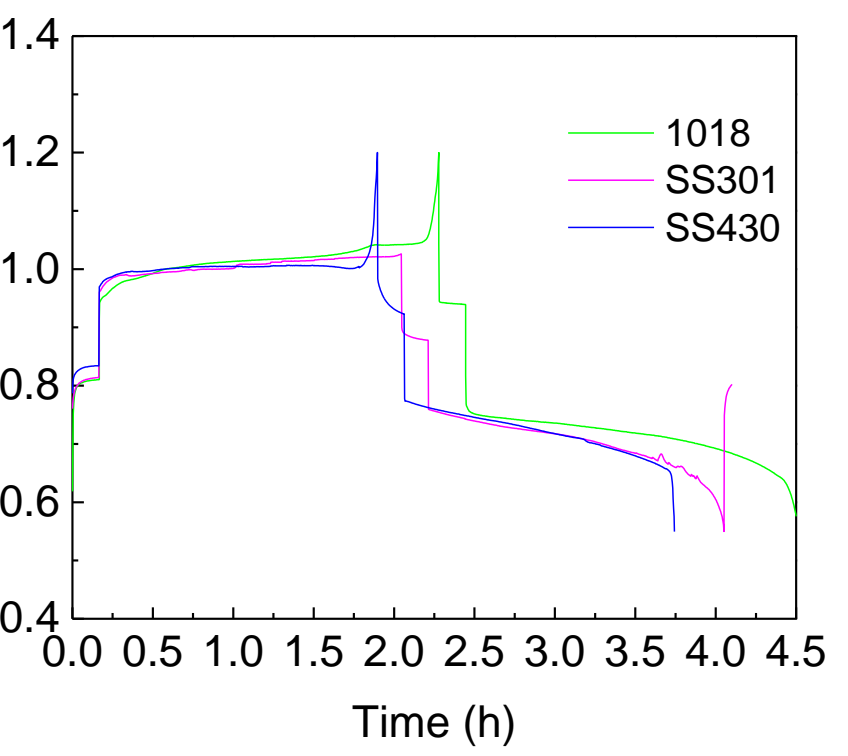

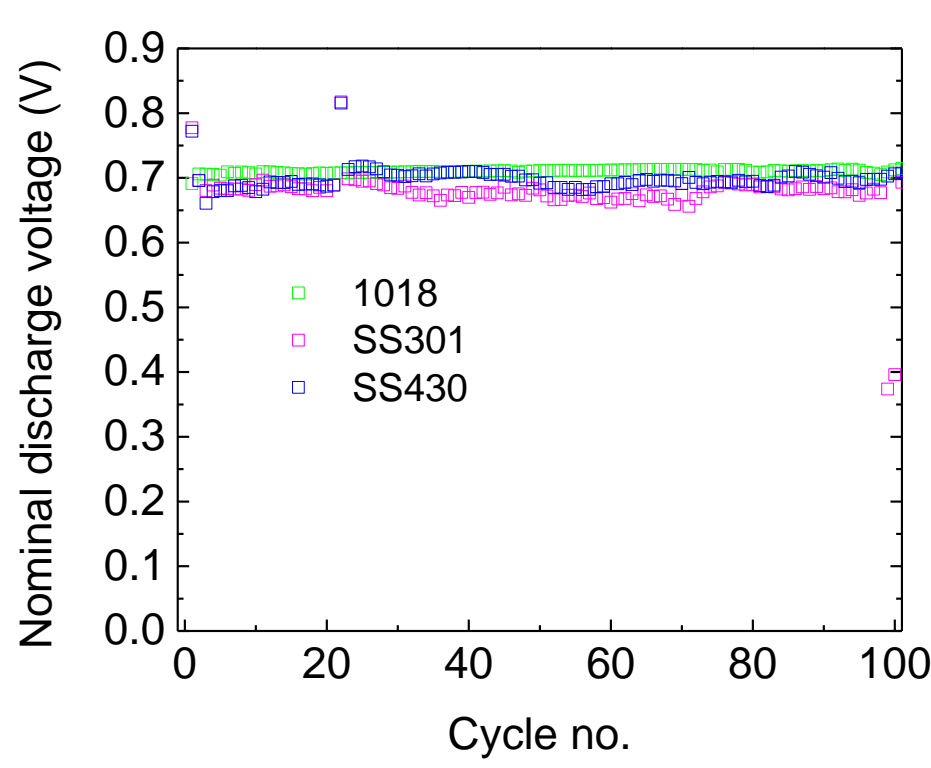

(c)

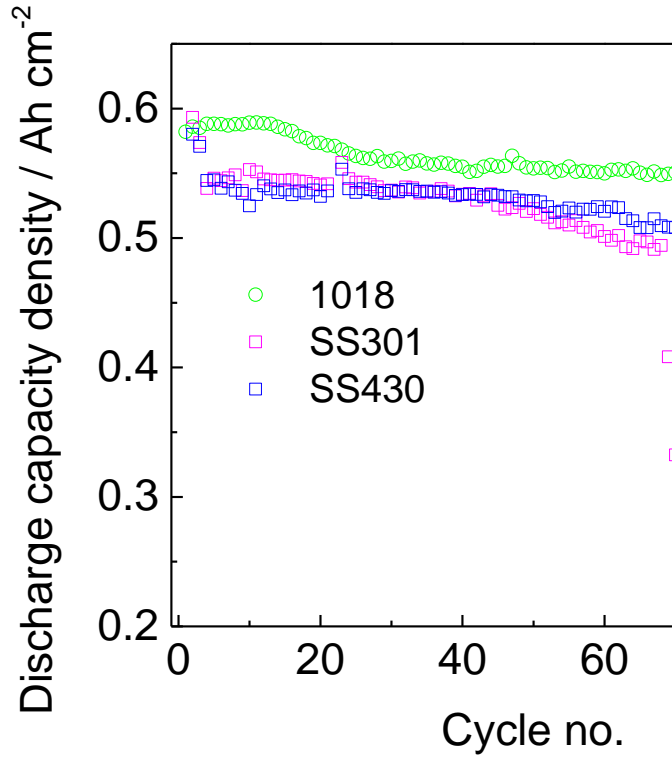


Fig. 6

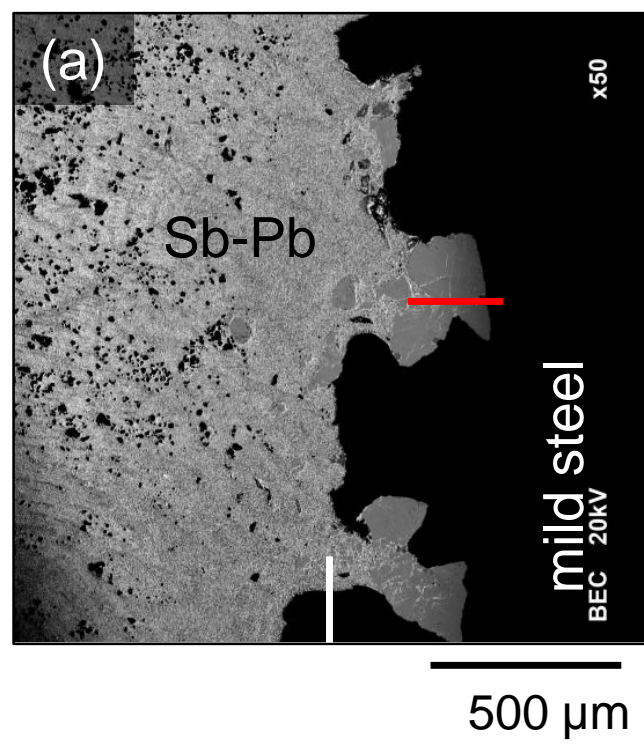

(d)
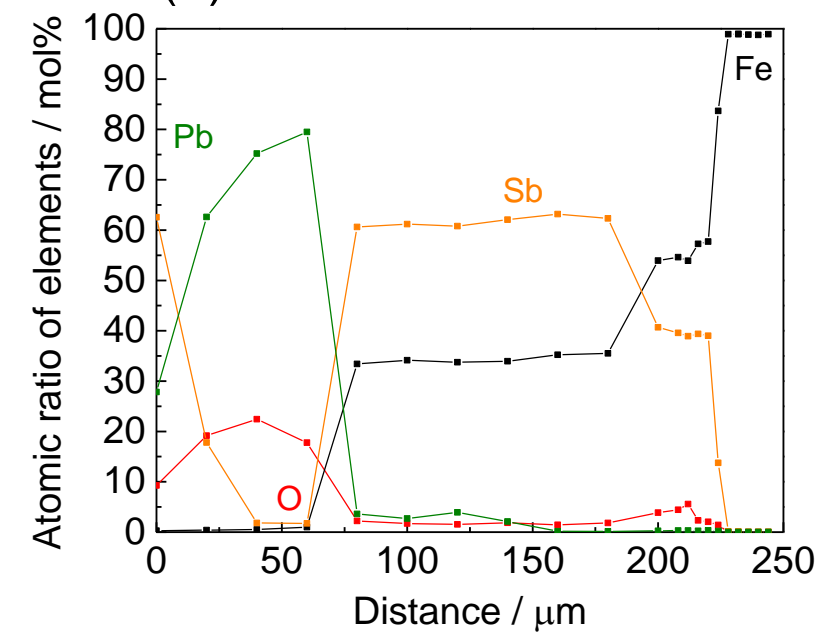

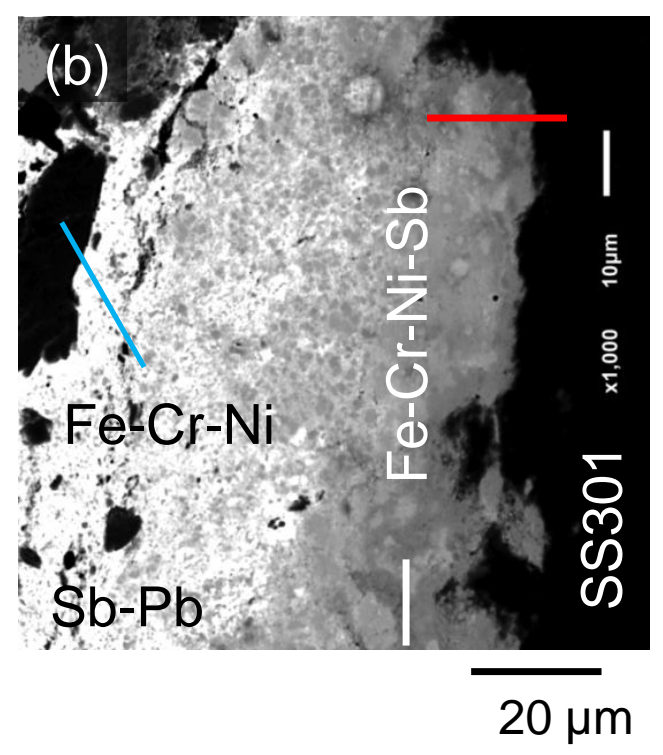

(e)

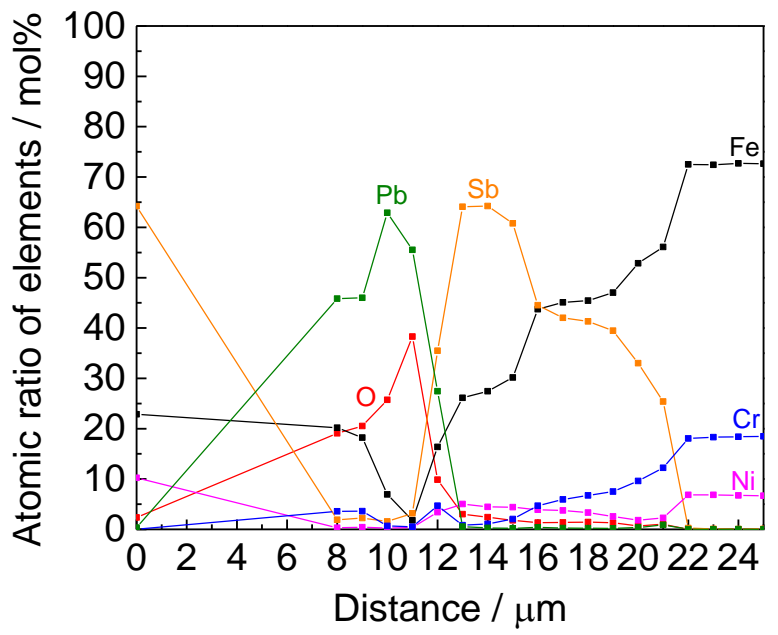

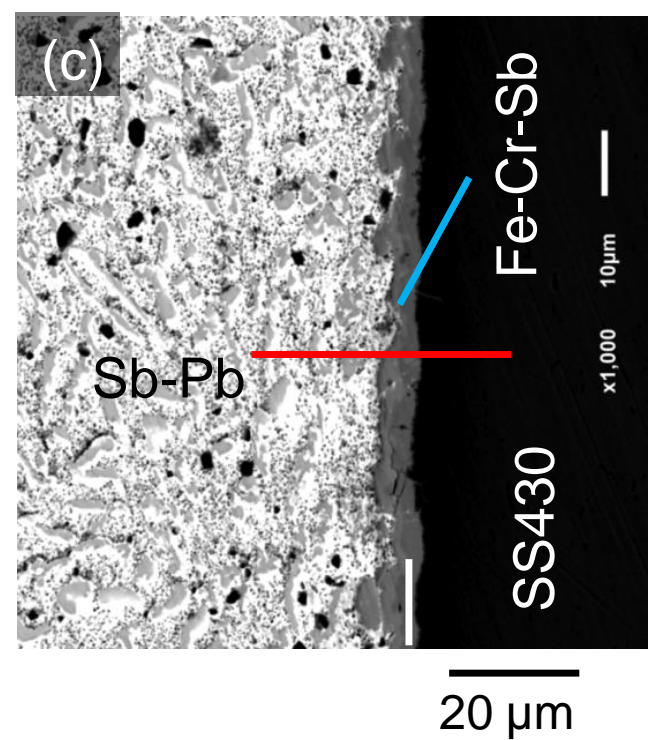

(f)

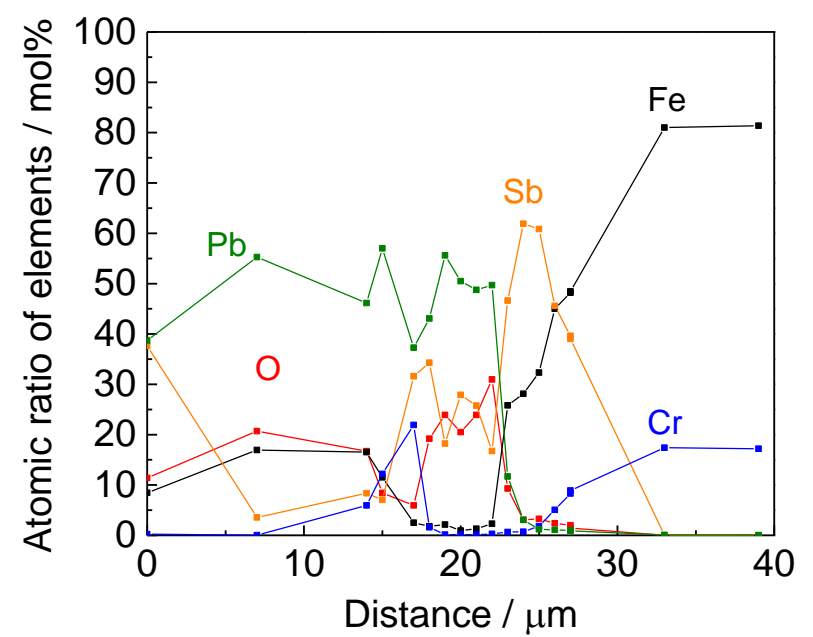


Fig. 7

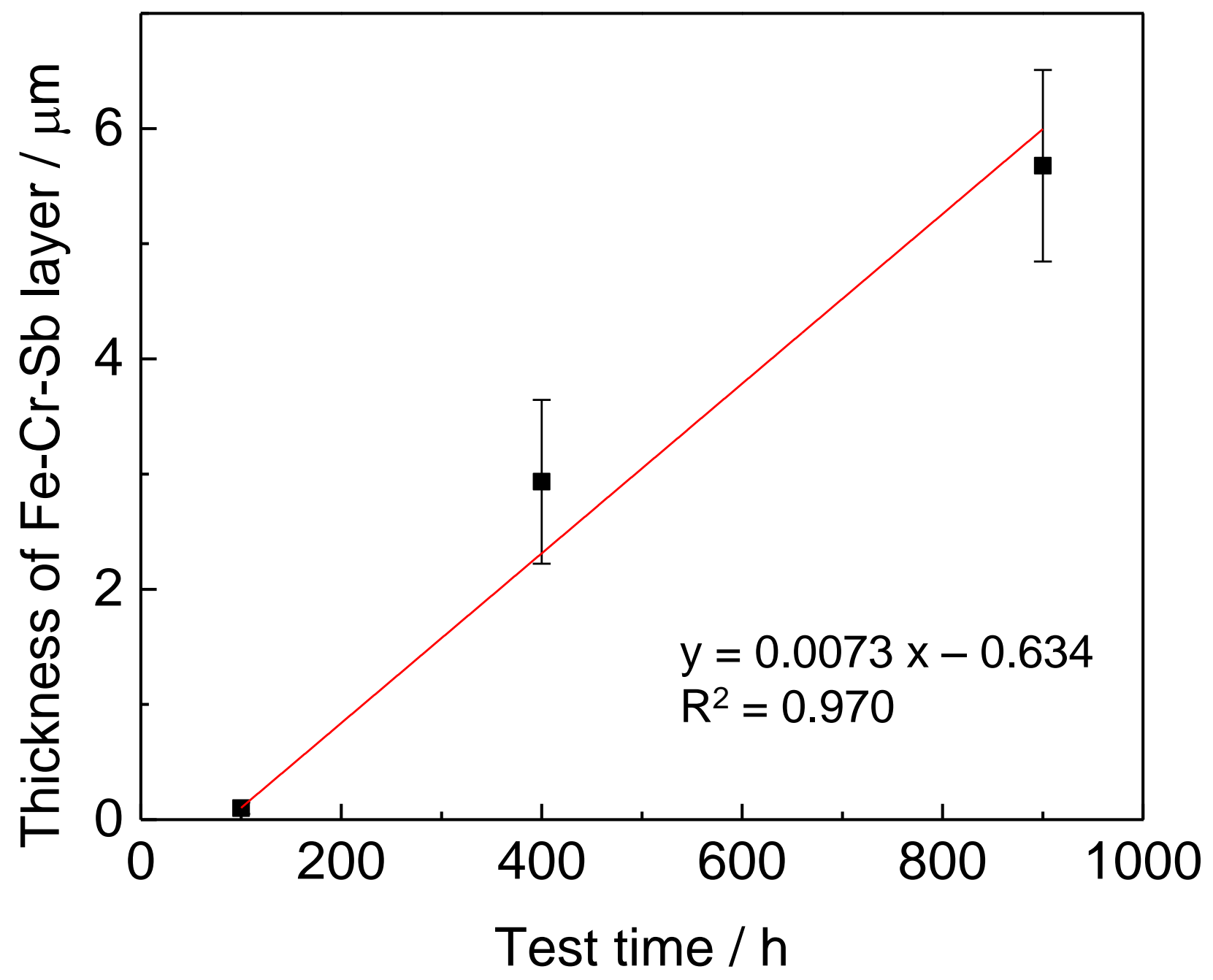




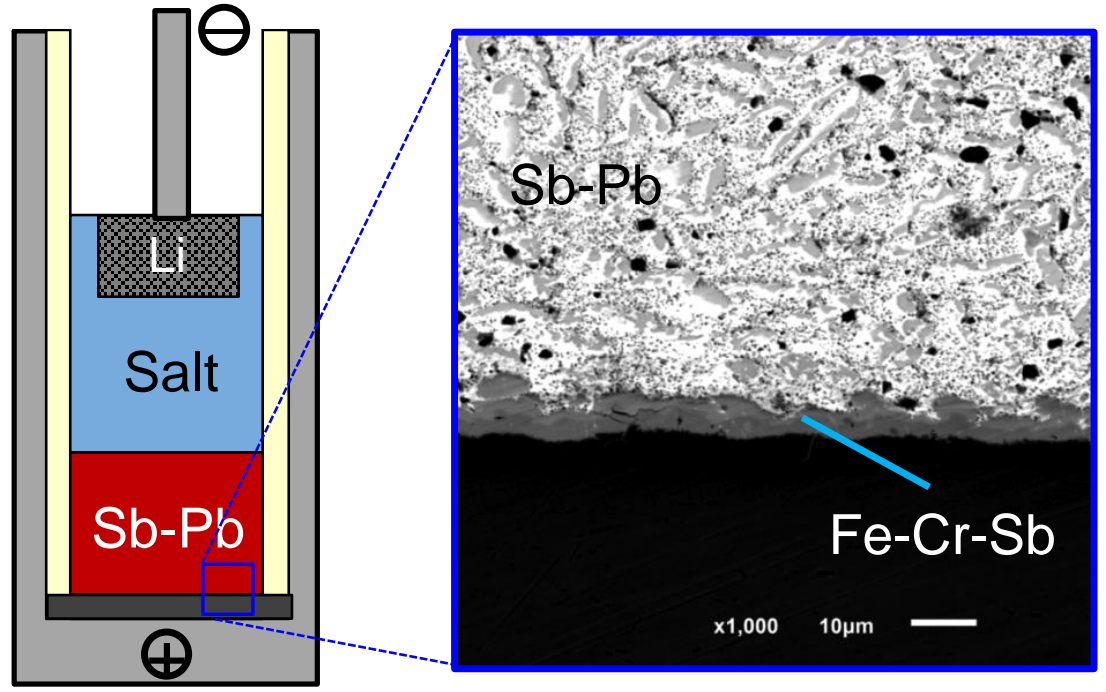

